\title{
Long-Term Exposure of Binary Mixture of Cadmium And Mercury Through Alteration of Nrf2 Signalling Pathway Damages The Developed Ovary of Zebrafish
}

\section{Utsav N Patel}

College of Veterinary Science and A.H., Junagadh

Urvesh D Patel ( $\sim$ urvesh1981@yahoo.com)

Department of Veterinary Pharmacology and Toxicology, College of Veterinary Science and A.H., Junagadh, Kamdhenu University https://orcid.org/0000-0002-0580-5356

\section{Aniket V Kadayata}

College of Veterinary Science and A.H., Junagadh

\section{Rahul K Vaja}

College of Veterinary Science and A.H., Junagadh

\section{Chirag M Modi}

College of Veterinary Science and A.H., Junagadh, Kamdhenu University

\section{Harshad B Patel}

College of Veterinary Science and A.H., Junagadh, Kamdhenu University

\section{Research Article}

Keywords: $\mathrm{Cd}$ and $\mathrm{Hg}$ exposure, oxidative stress, gene expression, histological changes, ovary

Posted Date: September 8th, 2021

DOI: https://doi.org/10.21203/rs.3.rs-840262/v1

License: (a) (i) This work is licensed under a Creative Commons Attribution 4.0 International License. Read Full License 


\section{Abstract}

The toxicity of the binary mixture of cadmium $(\mathrm{Cd})$ and mercury $(\mathrm{Hg})$ on the ovary of adult zebrafish was evaluated in the present study. Adult female zebrafish were exposed to cadmium chloride $(1 \mathrm{mg} / \mathrm{L})$, mercury chloride $(30 \mu \mathrm{g} / \mathrm{L})$ and a binary mixture of both metals for 21 days. The toxic effects of both metals on the ovary were investigated by evaluating the oxidative stress markers and related gene expression in ovarian tissue along with the histopathological examination. The significantly decreased level of GSH and increased level of MDA in ovarian tissue of adult female zebrafish exposed to $\mathrm{Cd}+\mathrm{Hg}$ indicated that the exposure of binary mixture of $\mathrm{Cd}$ and $\mathrm{Hg}$ caused more lipid peroxidation in the ovary. The decreased expression of mRNA of catalase (CAT) and Nuclear factor erythroid 2 (NF-E2)-related factor 2 (Nrf2) were observed in the ovary of zebrafish exposed to binary mixture. The down regulation of Nrf2 might be responsible for suppression of the antioxidant system which resulted in cellular alterations in the ovary. Upon histological evaluation, a decreased number of full-growth (mature) oocytes along with degenerative changes due to $\mathrm{Cd}$ exposure were noticed. While, ovary of zebrafish of $\mathrm{Hg}$-exposed group had shown decreased number of pre- and early-vitellogenic oocytes along with atretic pre-vitellogenic oocytes compared to the control group. The ovary of zebrafish of $\mathrm{Cd}+\mathrm{Hg}$-exposed group had shown decreased number of pre-vitellogenic oocytes with marked pathological changes in mature oocytes. Present findings elucidate that simultaneous long-term exposure of $\mathrm{Cd}$ and $\mathrm{Hg}$ may significantly affect the ovary through alteration of Nrf2 mediated cascade in adult zebrafish.

\section{Introduction}

The presence of pollutants in air and water sources because of industrial plants nearby residential areas is a critical situation for the health of humans and animals. Diverse pollutants are being discharged mainly into air and water resources, which also affects the health of aquatic animals. Amongst all pollutants, heavy metals cause intense harmful consequences on aquatic animals due to their high toxicity potential with environmental persistence (Srikanth et al. 2013). Cadmium (Cd) and mercury (Hg) are placed in upper position in the list of toxic metals and the levels of them in the environment are increasing. The metals like $\mathrm{Cd}$ and $\mathrm{Hg}$ can greatly accumulate in the brain, liver and kidneys of humans and animals after continuous exposure (Liao et al. 2006; Mieiro et al. 2011 ${ }^{\mathrm{a}, \mathrm{b}}$ ). Nevertheless, the both metals can also accumulate in other organs such as gonads (ovary and testis), which may affect reproductive efficiency (Liao et al. 2006).

Cadmium remains in the environment without degradation and causes harmful effects to humans and animals (Van Dyk et al. 2007). Mercury is also found in the aquatic environment with the ability to cause bioaccumulation in the aquatic species (Gworek et al. 2016). After consumption of such fish and other aquatic food animals, $\mathrm{Hg}$ enters in the body of humans and causes severe pathological alterations. Individually, $\mathrm{Cd}$ and $\mathrm{Hg}$ has been reported to alter the antioxidant system. Nuclear factor-erythroid 2 related factor 2 (Nrf2) has an important role to stimulate the antioxidant system (Lungu-Mitea et al. 2014). Significant down-regulation of Nrf2 has been observed in the brain of zebrafish following 
exposure to binary mixture of $\mathrm{Cd}$ and $\mathrm{Hg}$ (Patel et al. 2021). However, exposure of zebrafish to binary mixture of $\mathrm{Cd}$ and $\mathrm{Hg}$ didn't produce the significant additive or synergistic toxic effect on brain.

Higher level of cadmium as well as mercury has been reported in water resources (Patel and Vediya, 2012) as a result of anthropogenic activity. The Cd exposure at higher level causes the damage to multiple organs. Even in zebrafish the exposure of $\mathrm{Cd}$ at $1.05 \mathrm{mg} / \mathrm{L}$ for 21 days has been reported to affect the liver and ovary of zebrafish (Sunaina and Ansari, 2015). Similarly, marked pathological lesions in brain of zebrafish have been reported following exposure to $\mathrm{Cd}$ at $1.0 \mathrm{mg} / \mathrm{L}$ concentration for 16 days (Favorito et al. 2011). Likewise, severe oxidative stress-mediated changes in hypothalamic-pituitarygonadal axis of zebrafish have been reported following long-term exposure of mercury chloride (Zhang et al. 2016 $)$. Severe oxidative stress in gonads of zebrafish has been reported when fish exposed to $\mathrm{Hg}$ at $30 \mu \mathrm{g} / \mathrm{L}$ for 30 days (Zhang et al. $2016^{\mathrm{a}}$ ). Additionally, binary mixture of the $\mathrm{Hg}$ and $\mathrm{Cd}$ has been reported to alter the embryonic development in pregnant golden hamsters (Gale, 1973). However, Cd has been reported to counteract the biochemical and histological alterations in organs of Snakehead fish (Arya and Sharma, 2015). The lipid peroxidation is caused in ovary of zebrafish following individual exposure to $\mathrm{Cd}$ and $\mathrm{Hg}$ (Jin et al. 2015; Zheng et al. 2016). In fish, hypothalamus-pituitary-gonadal axis plays crucial role in regulation of reproductive functions (Ankley et al. 2010) through hormones secreted from them. Through disturbance of endocrine system, heavy metal-induced reproductive toxicity is well studied in fish (Ankley et al. 2010; Kwon et al. 2016; Su et al. 2016; Zhang et al. 2016 ${ }^{\mathrm{a}, \mathrm{b}}$ ). The reports related to heavy metal-induced oxidative stress mediated reproductive toxicity are limited and little information is available on toxic effects of metals like $\mathrm{Cd}$ and $\mathrm{Hg}$ on ovary of aquatic animals following individual and simultaneous exposure.

The zebrafish (Danio rerio), a popular lower vertebrae animal model that is widely used in toxicity studies particularly in the field of reproductive and neurotoxicity. Toxicity potential of $\mathrm{Cd}$ and $\mathrm{Hg}$ following individual exposure in various species of animals have been studied well. However, in the real field condition, there is exposure of more than one metal in aquatic animals at a time. It is the need to evaluate the ovarian toxicity potential of a mixture of heavy metals which persist at high concentration in the environment. The evaluation of alterations of oxidative stress markers, expression of antioxidant genes and histological changes in the ovary of adult zebrafish would be useful to understand the toxicity potential of such heavy metals following simultaneous exposure. Thus, the present study was planned to evaluate the ovarian toxicity following single and combined exposure of $\mathrm{Cd}$ and $\mathrm{Hg}$ in adult zebrafish. As per our knowledge, this is the first report which explores the effect of co-exposure of $\mathrm{Cd}$ and $\mathrm{Hg}$ on the developed ovary of adult zebrafish in terms of status of antioxidant system, gene expression and histological changes.

\section{Materials And Methods}

\section{Chemicals}


Analytical grade cadmium chloride $\left(\mathrm{CdCl}_{2}\right)$ and mercury chloride $\left(\mathrm{HgCl}_{2}\right)$ were purchased from Himedia, Mumbai (CAS number - 35658-65-2) and Merck, Mumbai (CAS number- 7487-94-7), respectively. Other chemicals used in the analysis were of molecular or analytical grade.

\section{Experimental animals and environment}

Adult female zebrafish (Wild-type) of 5-6 months of age were procured from Vikrant aqua culture, Mumbai. Fish were kept in tanks having capacity of $20 \mathrm{~L}$ with fitting of aerators. Two weeks of acclimation period were monitored before starting the experiment. Temperature of the water in the tank was in the range of $25-28^{\circ} \mathrm{C}$ and light/dark cycle of $14: 10 \mathrm{~h}$ was also maintained. The fish were fed with equal quantities of freeze-dried blood worms (Hallofeed $\circledast$, Maharashtra Aquarium-Mumbai) and fish pellets (Tetra bits complete ${ }^{\circledR}$, Tetra GmbH-Germany) $(10 \mathrm{mg} /$ fish twice a day freely available to each group). The filtered reverse osmosis (RO) water (pH of water: 6.8-7.4, Hardness: $200-250 \mathrm{mg} / \mathrm{L}$, Electrical conductivity: 500-600 $\mu \mathrm{s}$ ) was used during the experiment to maintain the fish.

\section{Experimental design}

In the study, the levels of exposure of both heavy metals were selected based on previous studies related to toxicity of cadmium (Favorito et al. 2011) and mercury (Zhang et al. 2016 ${ }^{\mathrm{a}}$ ). A total of $136 \mathrm{fish}$ used for this study which were randomly divided into four groups (34 fish in each group). Fish of the control group were kept untreated. Second group of fish was exposed to cadmium chloride dissolved in water (1 $\mathrm{mg} / \mathrm{L})$. Third group was exposed to mercury chloride dissolved in water $(30 \mu \mathrm{g} / \mathrm{L})$. Fourth group was exposed to both heavy metals in combination at the above specified strength. The exposure of fish to heavy metal/s was continued for 21 days. The used strength of both metals in a binary mixture form in the study has created more practical or environmental realistic exposure in the fish. Both metals were accurately weighted using precise analytical weighing balance (Model: MS 204S/A01, Mettler Toledo, US). The concentration of metal/s in each tank was maintained by changing the water daily with fresh water containing particular strength of metal/s. After an exposure period of 21 days, oxidative stress markers in the ovary were evaluated using 96 zebrafish (24 in each group; pooled samples and 6 replication). While, 20 fish were used for evaluation of expression of antioxidant genes in the ovarian tissue (5 from each group). Histological changes in the ovary were also observed microscopically using 20 zebrafish (5 from each group).

All fish were humanely sacrificed by the ice-cold method on 22nd day of the experiment. The ovary of each fish was dissected under Stereo Microscopes (Model CZM6, Labomed Inc., USA). The dissection of the ovary from zebrafish was completed approximately within a minute. Samples of ovary from 24 zebrafish were collected in Tris-EDTA buffer $(8.5 \mathrm{pH}$ to evaluate the activity of SOD (Samples from 6 fish/group). For evaluation of CAT activity and level of GSH, samples from 48 fish (12 fish/group; a pooled sample from 2 zebrafish) were collected phosphate buffer saline (7.4 pH; PBS). Samples of ovary from 24 zebrafish were collected in a butylated hydroxytoluene buffer to estimate the MDA level. For histopathological examination, 05 whole fish from each group were collected in $10 \%$ Neutral Buffered Formalin (NBF). Few incisions on the body of each fish were made to facilitate the penetration of 
buffered formalin in the body. In addition to this, the tissue samples of the ovary from 5 fish of each group (5 replications) were washed with PBS and collected in a nuclease-free storage vial containing RNAlater solution (Invitrogen, Bangalore, India) and processed for isolation of RNA and complementary DNA (cDNA) synthesis to study the mRNA expressions of sod, cat, and nrf2 genes.

\section{Evaluation of oxidative stress markers in ovarian tissue}

The SOD activity in the tissue was assayed using the method of pyrogallol autoxidation by superoxide radicals (Marklund and Marklund, 1974). Catalase (CAT) activity was determined according to the method described earlier (Sinha, 1972). The GSH level in the ovarian tissue was estimated using a method described by Ellman (1959). The level of malondialdehyde (MDA) in the sample was measured using steps described in the product catalog of Sigma-Aldrich Co. LLC., USA (Catalog number MAK085). ELISA plate reader (Thermofisher Scientific, Model: Multiskan Go) was used to measure the absorbance.

\section{Evaluation of expression of genes}

Trizol reagent (Ambion Life Technologies, USA) was used to extract total RNA from ovarian tissue as per the standard procedures described by Sambrook and Russel (2001). Nano-Drop spectrophotometer (ND2000 , Thermo scientific, USA) was used to check the quantity and quality of total RNA isolated. The sample of RNA with 260/280 ratio between 1.8 and 2.0 were further processed to remove the residual genomic DNA contamination using DNA-free ${ }^{T M}$ Kit (Ambion Life Technologies, USA). Complementary DNA (cDNA) was synthesized from total RNA using the first-strand cDNA synthesis kit (Genetix Biotech Asia Pvt. Ltd, New Delhi, India) as per the manufacturer's instructions. High-performance liquid chromatography (HPLC) purified primers (Eurofins Genomics India Pvt. Ltd., Bangalore, India) were used for amplification of genes viz. sod, cat, nrf2, and $\beta$-actin are mentioned in Table 1 . The target and housekeeping genes were amplified in a real-time PCR system (LightCycler® 480 II, Roche, Switzerland), using Maxima $^{\text {TM }}$ SYBR Green/ROX qPCR Master Mix (Genetix Biotech Asia Pvt. Ltd, New Delhi, India).

Amplifications for each mRNA were performed with the cDNA template and fold expression analysis was carried out $2^{-\triangle \Delta C t}$ method by keeping $\beta$-actin as the endogenous control gene (Livak and Schmittgen, 2001). 
Table 1

Sequences of primers of targeted genes used for real-time PCR amplification

\begin{tabular}{|c|c|c|c|c|}
\hline $\begin{array}{l}\text { Target } \\
\text { gene }\end{array}$ & Primer sequence $\left(5^{\prime}-3^{\prime}\right)$ & $\begin{array}{l}\text { Annealing } \\
\text { temperature }\left({ }^{\circ} \mathrm{C}\right)\end{array}$ & $\begin{array}{l}\text { Product } \\
\text { size } \\
\text { (bp) }\end{array}$ & Reference \\
\hline \multirow[t]{2}{*}{ sod } & $\begin{array}{l}\text { FP 5'- } \\
\text { CAACACAAACGGCTGCATCA - } \\
3^{\prime}\end{array}$ & 60 & 132 & $\begin{array}{l}\text { (Sarkar et al., } \\
\text { 2014) }\end{array}$ \\
\hline & $\begin{array}{l}\text { RP 5'- } \\
\text { TTTGCAACACCACTGGCATC - } \\
3^{\prime}\end{array}$ & & & \\
\hline \multirow[t]{2}{*}{ cat } & $\begin{array}{l}\text { FP 5'- } \\
\text { AGTTCCCTCTGATTCCTGTG - } \\
3^{\prime}\end{array}$ & 60 & 173 & $\begin{array}{l}\text { (Jaramillo et al., } \\
\text { 2017) }\end{array}$ \\
\hline & $\begin{array}{l}\text { RP 5'- } \\
\text { ATGGCGATGTGTGTCTGG - 3' }\end{array}$ & & & \\
\hline \multirow[t]{2}{*}{ Nrf2 } & $\begin{array}{l}\text { FP 5'- } \\
\text { TGTTGGTTCGGAGGCTCTTAA } \\
-3^{\prime}\end{array}$ & 60 & 62 & $\begin{array}{l}\text { (Velasques et al., } \\
\text { 2016) }\end{array}$ \\
\hline & $\begin{array}{l}\text { RP 5'- } \\
\text { AGGCCATGTCCACACGTACA - } \\
3^{\prime}\end{array}$ & & & \\
\hline \multirow[t]{2}{*}{$\beta$-actin } & $\begin{array}{l}\text { FP 5'- } \\
\text { GCTGTTTTCCCCTCCATTGTT - } \\
3^{\prime}\end{array}$ & 60 & 60 & $\begin{array}{l}\text { (Bautista et al., } \\
\text { 2018) }\end{array}$ \\
\hline & $\begin{array}{l}\text { RP 5'- } \\
\text { TCCCATGCCAACCATCACT - } 3^{\prime}\end{array}$ & & & \\
\hline
\end{tabular}

SOD: superoxide dismutase, CAT: catalase, Nrf2: Nuclear factor erythroid 2 (NF-E2)-related factor 2

\section{Histopathological examination}

The formalin-fixed fish were placed in sodium EDTA solution ( $0.35 \mathrm{M}, \mathrm{pH} 7.8)$ for decalcification for 7 days. The volume of sodium EDTA solution was 20 times the fish volume. The decalcified fish were embedded in paraffin which was used to get sections of $5 \mu$ thickness using a semi-automated rotary microtome (Leica Biosystems, Germany). Tissue sections were stained with hematoxylin and eosin ( $\mathrm{H}$ \& E) stains. The stained slides were observed for microscopic pathological changes in the ovary using an optical microscope (Zeiss primo star) attached with a microscopic camera (ZEISS Axiocam ERc 5) and digital histological photographs were captured with the help of Carl Zeiss ZEN 2 (Blue edition) software.

\section{Statistical analysis}

Statistical analyses of all data were carried out using GraphPad prism. Kolmogorov-Smirnov test was used to evaluate the normality of data along with Bartlett's test to confirm the equal variance. All data 
were analyzed by parametric one way analysis of variance (ANOVA) followed by Tukey's HSD test as they were found with normal distribution and homogeneous variance. The value of $p<0.05\left(^{*}\right)$ was considered as statistically significant and $p<0.01(* *), p<0.005(* * *)$ and $p<0.001(* * \star *)$ were considered for highly statistical significant differences.

\section{Results}

Oxidative stress markers evaluated in ovarian tissue of zebrafish of different groups are presented in the Fig. 1. The SOD activity in ovarian tissue was not significantly $(p>0.05)$ altered in zebrafish of all toxicity groups. While, CAT activity in the zebrafish exposed to $\mathrm{Cd}+\mathrm{Hg}$ was non-significantly lower than those of other groups. The levels of GSH in the ovarian tissue of $\mathrm{Cd}$ - and $\mathrm{Hg}$-exposed zebrafish were slightly lower (non-significant) $(p>0.05)$ than that of the control group. However, the ovarian tissue of zebrafish exposed to $\mathrm{Cd}+\mathrm{Hg}$ had shown a significantly lower level of GSH $(p<0.01)$ as compared the control group $(p<0.05)$. The MDA level of the ovary was slightly $(p>0.05)$ higher in zebrafish exposed to $\mathrm{Cd}$ and $\mathrm{Hg}$ alone as compared to that of the control group. However, that of the $\mathrm{Cd}+\mathrm{Hg}$-exposed group was significantly $(p<0.001)$ high as compared to that of the control group.

The expression levels of mRNA of SOD, CAT, and Nrf2 of ovary of zebrafish from different groups are given in Table 2. PCR amplification of $\beta$-actin (BA), CAT, SOD, Nrf2 from the ovarian tissue of adult zebrafish is shown in Fig. 2. The expression levels of SOD mRNA in all toxicity groups were slightly increased (non-significantly) as compared to control group. The CAT mRNA expression level in the ovary of zebrafish exposed to $\mathrm{Cd}+\mathrm{Hg}$ was 4.92 fold lower than that of control group $(p>0.05)$. Similarly, expression level of Nrf2 mRNA in ovary of zebrafish exposed to $\mathrm{Cd}+\mathrm{Hg}$ was also 7.08 fold lower than that of control group $(p>0.05)$. 
Table 2

SOD, CAT and Nrf2 mRNA expression in the ovary of adult zebrafish exposed to $\mathrm{Cd}, \mathrm{Hg}$ and $\mathrm{Cd}+\mathrm{Hg}$ for 21 days

\begin{tabular}{|c|c|c|c|c|}
\hline $\begin{array}{l}\text { mRNA } \\
\text { expression }\end{array}$ & $\begin{array}{l}\text { Toxicity } \\
\text { group }\end{array}$ & $\Delta \Delta C$ ct value & $\begin{array}{l}\text { Fold changes } \\
\left(2^{-\Delta \Delta C t}\right)\end{array}$ & Change in expression \\
\hline \multirow[t]{3}{*}{ SOD } & $\mathrm{Cd}$ & $2.96 \pm 1.18^{a}$ & 0.13 & Increase \\
\hline & $\mathrm{Hg}$ & $5.01 \pm 0.70^{a}$ & 0.03 & Increase \\
\hline & $\mathrm{Cd}+\mathrm{Hg}$ & $3.08 \pm 0.77^{a}$ & 0.12 & Increase \\
\hline \multirow[t]{3}{*}{ CAT } & $\mathrm{Cd}$ & $\begin{array}{l}-1.99 \pm 1.27 \\
\mathrm{a}\end{array}$ & 3.98 & Decrease \\
\hline & $\mathrm{Hg}$ & $\begin{array}{l}-1.52 \pm 0.80 \\
a\end{array}$ & 2.88 & Decrease \\
\hline & $\mathrm{Cd}+\mathrm{Hg}$ & $\begin{array}{l}-2.03 \pm 1.04 \\
\text { a }\end{array}$ & 4.92 & Decrease \\
\hline \multirow[t]{3}{*}{ Nrf2 } & $\mathrm{Cd}$ & $\begin{array}{l}-0.90 \pm 1.52 \\
\text { a }\end{array}$ & 1.87 & Decrease \\
\hline & $\mathrm{Hg}$ & $\begin{array}{l}-2.33 \pm 0.86 \\
a\end{array}$ & 5.02 & Decrease \\
\hline & $\mathrm{Cd}+\mathrm{Hg}$ & $\begin{array}{l}-2.82 \pm 0.56 \\
\text { a }\end{array}$ & 7.08 & Decrease \\
\hline
\end{tabular}

Cd: group exposed to cadmium chloride, $\mathrm{Hg}$ : group exposed to mercury chloride, $\mathrm{Cd}+\mathrm{Hg}$ : group exposed to cadmium chloride along with mercury chloride. Data were analyzed one-way ANOVA followed by Tukey's HSD test. No significant difference between groups $(p>0.05)$

Upon microscopic examination, the ovary of normal zebrafish revealed normal architecture of oocytes of various developmental stages (pre-vitellogenic oocyte (PVO), early-vitellogenic oocyte (EVO) and fullgrowth (Mature) oocyte (FGO) (Fig. 3A \& B). Early-vitellogenic oocyte stage is also called the cortical alveoli stage. The ovary of cadmium-exposed zebrafish had shown decreased number of FGO, increased number of PVO and EVO with loss of contacts between the oocyte cell membrane and the follicular cell layer (Fig. 4A). Various alterations like accumulation of proteinaceous fluid in EVO and FGO, degenerated PVO, atretic EVO and atretic PVO were noticed (Fig. 4B, C \& D). The ovary of mercury-exposed zebrafish had shown accumulation of proteinaceous fluid (Degenerative changes) in EVO, degenerated FGO and atretic PVO (Fig. 5A to D). Ovary of zebrafish exposed to cadmium along with mercury had shown disorganized structure of FGO, depletion of yolk granules in FGO, accumulation of proteinaceous fluid in EVO and FGO, and atretic PVO (Fig. 6A to D).

The values of no. of oocytes at different stages in the ovary of adult zebrafish of different groups are shown in Fig. 7. No. of atretic pre-vitellogenic and early-vitellogenic and mature oocytes with degenerative changes in the ovary of adult zebrafish of different groups are shown in Fig. 8. In the control group, the 
number of PVO, EVO and FGO were 45.76, 24.80 and $29.44 \%$, respectively. The Cd-exposed zebrafish exhibited significant increase of PVO and decrease in FGO compared to control fish. However, no significant effect of $\mathrm{Cd}$ was noticed on the number of EVO. The fish exposed to either $\mathrm{Hg}$ or $\mathrm{Cd}+\mathrm{Hg}$ showed the significant decrease of PVO and EVO compared to the control and the Cd group. However, there was no significant difference in the number of PVO, EVO and FGO between $\mathrm{Hg}$ and $\mathrm{Cd}+\mathrm{Hg}$ exposed groups. Compared to other toxicity groups, $\mathrm{Cd}$ exposure resulted in the significantly higher no. of atretic PVO. Similarly, $\mathrm{Cd}+\mathrm{Hg}$ exposure resulted in the significant higher no. of EVO with degenerative changes. Interestingly, no. of FGO with degenerative changes was significantly higher in the $\mathrm{Cd}$ - and $\mathrm{Hg}$-exposed groups as compared to control group. However, almost all FGO of $\mathrm{Cd}+\mathrm{Hg}$ group showed structural damage with depletion of yolk granules as compared to that observed following individual exposure of $\mathrm{Cd}$ or $\mathrm{Hg}$.

\section{Discussion}

The data related to the reproductive toxicity potential of binary mixture of $\mathrm{Cd}$ and $\mathrm{Hg}$ in laboratory animals, especially in zebrafish, are scarce. As per our knowledge, this is the first report which includes the findings related to effect of binary mixture of $\mathrm{Cd}$ and $\mathrm{Hg}$ on developed ovary of adult zebrafish exposed for longer duration. We focused on evaluation of oxidative insult along with mRNA expression levels of related genes in the ovary of adult zebrafish. We also observed important histological changes in the ovarian distribution of various types of oocytes along with histological changes in the ovary of adult zebrafish exposed to both $\mathrm{Cd}$ and $\mathrm{Hg}$ individually or $\mathrm{Cd}+\mathrm{Hg}$ for a long time. Thus, the findings of the study may be helpful to understand or explore the risk hazard when animals or humans are exposed continuously to both metals at a time.

In line of our observations related to antioxidant enzymes in the present study, in the ovary of zebrafish, a significantly decreased GPx activity and GSH content with little or no effect on the activity of CAT and SOD after 30 days of exposure of $\mathrm{Hg}$ has been reported previously (Zhang et al. 2016 ${ }^{\mathrm{a}}$ ). However, $\mathrm{Cd}$ exposure for 21 days at high dose in zebrafish has been reported to cause significant decrease of CAT, SOD, GPx activity along with higher level of MDA in the ovary (Banni et al. 2011, Sunaina and Ansari, 2015). Cadmium leads to increase the oxidative stress through production of the hydroxyl radical species which initiates the lipid peroxidation (Jurczuk et al. 2004; Dondero et al. 2005) and also alters the antioxidative stress enzymes (Bauer et al. 1980; Jihen et al. 2009). The less alteration in CAT activity by Cd and $\mathrm{Hg}$ in the ovary of zebrafish might be due to less accumulation of $\mathrm{H}_{2} \mathrm{O}_{2}$ and other cytotoxic radicals. The GSH specifically after binding with $\mathrm{Cd}$ and $\mathrm{Hg}$ forms a complex which prevents it's binding to cellular proteins, and therefore plays a critical role in the cellular regulation of detoxification. On the other hand, the MDA is an indicator of lipid peroxidation (LPO) which is a major contributor to the disruption of cell function under oxidative stress (Storey, 1996). The enhanced LPO in the ovary of fish exposed to $\mathrm{Cd}+\mathrm{Hg}$ might be due to inhibition of antioxidants enzymes, which are more concerned with defense against free radical induction. 
Following entry of heavy metals including $\mathrm{Cd}$ and $\mathrm{Hg}$, the antioxidant system at cellular level is altered (Regoli et al. 2002) through increasing the levels of reactive species. The heavy metals also alters the activities of antioxidant enzymes of aquatic animals through alterations in activity and levels of antioxidant enzymes, particularly SOD, CAT and GSH which provide the first line of cellular defense against the free radicals. The heavy metals causes cellular alterations following entry in the body and affects integrity of DNA (Druwe and Vaillancourt, 2010; Gonzalez et al. 2010; Bertin and Averbeck, 2006). The activation of Nrf2 is a master key process of the cellular antioxidant response. The ROS binds to antioxidant response element (ARE) sequence in the promoter region of antioxidant enzyme genes and activates gene expression (Osburn and Kensler, 2008). Nrf2 in its inactive form can binds to Kelch-likeECH-associated protein 1 (Keap1) which is inhibitor of Nrf2 which leads to alter the transcriptional activity (Sporn and Liby, 2012). Upon initiation of oxidative stress, the Nrf2 is liberated from Keap1 and translocated into the nucleus where it regulates the transcription of antioxidant genes (Dai et al. 2007). Till date, little information is available regarding the role of $\mathrm{Nrf2}$ in $\mathrm{Cd}$ and $\mathrm{Hg}$ induced oxidative stress in the ovarian tissue of adult zebrafish except few studies on other metals (Jiang et al. 2014; Zheng et al. 2016; Mondal et al. 2019). We also observed slightly up-regulation of expression level of SOD mRNA in the ovary of zebrafish of toxicity groups. The down-regulation of mRNA expression of NrF2 was accompanied with down-regulation of CAT mRNA expression in all toxicity groups. Similar to our observations, the significant up-regulation of the SOD mRNA expression along with non-significant decrease of SOD activity was reported in the ovary of zebrafish exposed to $\mathrm{Hg}(30 \mu \mathrm{g} / \mathrm{L})$ for 30 days. The CAT activity was also reported to be non-significantly affected (slightly lower) with the down-regulation of CAT mRNA in zebrafish exposed to $\mathrm{Hg}(30 \mu \mathrm{g} / \mathrm{L})$ (Zhang et al. 2016 $)$. The significant lower activities of SOD and CAT have been reported along with significant up-regulation of their relative genes in ovary of zebrafish following Cd exposure to $0.4 \mathrm{mg} / \mathrm{L}$ for 21 days (Banni et al. 2011). The up-regulated mRNA level of Nrf2 due to $\mathrm{Cd}$ exposure for $96 \mathrm{~h}$ has been reported with the up-regulation of Cu/Zn-SOD and CAT activity in the ovary of zebrafish (Zheng et al. 2016). The relatively stable activity of SOD and CAT along with expression of CAT mRNA in the ovary of zebrafish has been reported even though having an upregulated expression of SOD1 (Zhang et al. 2016 ${ }^{\mathrm{a}}$ ). Fish can combat the increased level of ROS in the body by producing scavenging enzyme such as SOD which converts superoxide anions into $\mathrm{H}_{2} \mathrm{O}_{2}$. It might be possible that an increase in the transcription of this gene would contribute to the elimination of $\mathrm{Cd}$ and $\mathrm{Hg}$-induced ROS from the cells. Continuous production of $\mathrm{H}_{2} \mathrm{O}_{2}$ in ovarian tissue may decrease the CAT activity and its relative mRNA expression level.

In line with our observations related to histological changes in the ovary, Cd exposure $(0.4 \mathrm{mg} / \mathrm{L}$ for 21 days) has been reported to cause the histological changes in the ovary of zebrafish. Such effects might be due to the down regulation of Zn transporter 1 (ZnT1) Zrt- and over-expression of Irt-related protein 10 (ZIP10) in zebrafish ovary (Chouchene et al. 2011). The ZIPs and ZnTs are involved in cytokine- and growth factor-mediated signalling, and the regulation of enzymes, receptors, and transcription factors of cellular signalling pathways. The $\mathrm{Hg}$ exposure has been reported to cause oocyte atresia, loss of contacts between the oocyte cell membranes and the follicular cell layer at different exposure levels (15 and 30 $\mu \mathrm{g} / \mathrm{L}$ for 30 days) in zebrafish (Zhang et al. 2016ª). The Cd co-exposed with $\mathrm{Hg}$ in the present study had 
shown significant down regulation of Nrf2 gene along with significant decrease of GSH content with increase of MDA level which indicates the possible toxicity potential of both metals following coexposure as compared to individual exposure. This finding was also supported with histological changes in the ovary like degenerative changes in FGO along with atresia of PVO and EVO with significant decrease in the no. of PVO and EVO. Nuclear factor-erythroid 2 -related factor 2 (Nrf2) is the primary transcription factor which regulates cytoprotective genes, including the antioxidant glutathione (GSH) and protects the cells from oxidative stress (Harvey et al. 2009). Nrf2 has an important role in maintaining the $\mathrm{GSH}$ redox state through transcriptional regulation of glutathione reductase and protecting cells against oxidative stress.

\section{Conclusions}

The result of the present study showed that the cadmium exposure resulted in more number of atretic previtellogenic oocytes along with reduced size of mature oocytes, while mercury exposure decreased the number of pre-vitellogenic oocytes without significant effect on size of mature oocytes. Such finding suggests that following long-term exposure of cadmium chloride alone may damage the mature and early-stage oocytes, while mercury chloride had shown ability to damage the oocytes at early stage in the ovary of adult zebrafish. Overall, from the results obtained in the study, it is inferred that waterborne exposure of cadmium along with the mercury causes significant oxidative stress-mediated histological damages through alterations of Nrf2 mediated signalling pathway in the ovary of zebrafish as compared to individual exposure, which may subsequently impair the reproduction capacity of fish.

\section{Declarations}

Ethics approval and consent to participate: Experimental procedure was approved by the Institutional Animal Ethics Committee of the college.

Consent for publication: All the authors approved the manuscript for publication.

Availability of data and materials: All data are made available in the manuscript and supplementary file.

Competing interests: The authors declare that they have no competing interests.

Funding: The research work was carried out from the funding available in the Department.

\section{Authors' contributions:}

Utsav N. Patel: investigation, validation, formal analysis, writing - original draft.

Urvesh D. Patel: conceptualization, writing - review and editing, supervision.

Rahul K. Vaja: investigation, data curation. 
Aniket V. Khadayata: investigation, data curation.

Chirag M. Modi: methodology, editing.

Harshad B. Patel: investigation, validation, formal analysis.

\section{Acknowledgement}

All authors are highly thankful to Dr. Amit R. Bhadaniya, Associate Professor, Department of Veterinary Pathology, College of Veterinary Science and Animal Husbandry, Junagadh, India for his help during the study. We are also thankful to Dr. B. B. Javia, Associate Professor, Department of Veterinary Microbiology and Dr. A.R. Ahlawat, Associate Professor, Department of Animal Genetics and Breeding, College of Veterinary Science and Animal Husbandry, Junagadh, India for providing the facility for this study.

\section{References}

1. Ankley GT, Jensen KM, Kahl MD, Durhan EJ, Makynen E A, Cavallin J E, Martinoviae D, Wehmas LC, Mueller ND, Villeneuve DL. (2010). Use of chemical mixtures to differentiate mechanisms of endocrine action in a smallfish model. Aquat Toxicol 99(389).

https://doi.org/10.1016/j.aquatox.2010.05.020

2. Arya, A. and Sharma, G. D. (2015). Combined effects of cadmium and mercury on some biochemical and histochemical changes in liver, kidney and gills of Channa Punctatus (Bloch). Int J Pharmacy Pharmaceut Sci 7(8): 117-

120. https://innovareacademics.in/journals/index.php/ijpps/article/view/5206

3. Banni M, Lina C, Said K, Kerkeni A. (2011). Mechanisms underlying the protective effect of zinc and selenium against cadmium induced oxidative stress in zebrafish (Danio rerio). Biol Metals 24(981). https://doi.org/10.1007/s10534-011-9456-z

4. Bauer R, Demeter I, Hasemann V, Johansen JT. (1980). Structural properties of the zinc site in Cu, Znsuperoxide dismutase; perturbed angular correlation of gamma ray spectroscopy on the $\mathrm{Cu},{ }^{111} \mathrm{Cd}$ superoxide dismutase derivative. Biochem Biophy Res Comm 94(1296). https://doi.org/10.1016/0006-291X(80)90560-4.

5. Bertin G, Averbeck D. (2006). Cadmium: cellular effects, modifications of biomolecules, modulation of DNA repair and genotoxic consequences (a review). Biochimie 88(1549).https://doi.org/10.1016/j.biochi.2006.10.001

6. Chouchene L, Banni M, Kerkeni A, Saïd K, Messaoudi I. (2011). Cadmium-induced ovarian pathophysiology is mediated by change in gene expression pattern of zinc transporters in zebrafish (Danio rerio). Chem Biol Interact 193(172). https://doi.org/10.1016/j.cbi.2011.06.010 _

7. Dai G, Vaughn S, Zhang Y, Wang ET, Garcia-Cardena G, Gimbrone Jr MA. (2007). Biomechanical forces in atherosclerosis-resistant vascular regions regulate endothelial redox balance via 
phosphoinositol 3-kinase/Akt-dependent activation of Nrf2. Circ Res 101(723).

https://doi.org/10.1161/CIRCRESAHA.107.152942

8. Dondero F, Piacentini L, Banni M, Rebelo M, Burlando B, Viarengo A. (2005). Quantitative PCR analysis of two molluscan metallothionein genes unveils differential expression and regulation. Gene 345(259). https://doi.org/10.1016/j.gene.2004.11.031

9. Druwe IL, Vaillancourt RR. (2010). Influence of arsenate and arsenite on signal transduction pathways: an update, Arch Toxico/ 84(585). https://doi.org/10.1007/s00204-010-0554-4_

10. Ellman G. Tissue sulfhydryl groups. Arch Biochem Biophys 82(1959) 70. https://doi.org/10.1016/0003-9861(59)90090-6

11. Favorito, R., Chiarelli, G., Grimaldi M.C., Bonis, S; Lancieri, M and Ferrandin, I. 2011. Bioaccumulation of cadmium and its cytotoxic effect on zebrafish brain.

J Chem Ecol 27 (sup2): 39-46. https://doi.org/10.1080/02757540.2011.625937

12. Gale, T.F. (1973). The interaction of mercury with cadmium and zinc in mammalian embryonic development. Environ Res. 6(1): 95-105. https://doi.org/10.1016/0013-9351(73)90022-4

13. Gonzalez HO, Hu J, Gaworecki KM, Roling JA, Baldwin WS, Gardea-Torresdey JL, Bain LJ. (2010).Dose-responsive gene expression changes in juvenile and adult mummichogs (Fundulus heteroclitus) after arsenic exposure. Mar Environ Res 70(133).

https://doi.org/10.1016/j.marenvres.2010.04.003

14. Gworek, B., Bemowska-Kałabun, O., Kijeńska, M. and Wrzosek-Jakubowska, J. 2016. Mercury in Marine and Oceanic Waters-a Review. Water Air Soil Pollut 227(10):

71. https://doi.org/10.1007/s11270-016-3060-3

15. Harvey CJ, Thimmulappa RK, Singh A, Blake DJ, Ling G, Wakabayashi N, Fujii J, Myers A, Biswal S. (2009). Nrf2-regulated glutathione recycling independent of biosynthesis is critical for cell survival during oxidative stress. Free Radic Biol Med 46

(443). https://doi.org/10.1016/j.freeradbiomed.2008.10.040

16. Jiang WD, Liu Y, Hu K, Jiang J, Li SH, Feng L, Zhou XQ. (2004). Copper exposure induces oxidative injury, disturbs the antioxidant system and changes the Nrf2/ARE (CuZn-SOD) signaling in the fish brain: protective effects of myo-inositol. Aquat Toxicol 155(301).

https://doi.org/10.1016/j.aquatox.2014.07.003

17. Jihen EH, Imed M, Fatima H, Abdelhamid K. (2009). Protective effects of selenium (Se) and zinc (Zn) on cadmium (Cd) toxicity in the liver of the rat: effects on the oxidative stress. Ecotoxicol Environ Safety 72(1559). https://doi.org/10.1016/j.ecoenv.2008.12.006

18. Jin, Y., Liu, Z., Liu, F., Yang, Y., Peng, T. and Fu, Z. (2015). Embryonic exposure to cadmium and chromium induce behavioral alterations, oxidative stress and immunotoxicity in zebrafish (Danio rerio). Neurotoxicol Teratol 48: 9-17. https://doi.org/10.1016/j.ntt.2015.01.002

19. Jurczuk M, Brzoska MM, Moniuszko-Jakoniuk J, Gałażyn-Sidorczuk M, Kulikowska-Karpińska, E. (2001). Antioxidant enzymes activity and lipid peroxidation in liver and kidney of rats exposed to cadmium and ethanol. Food Chem Toxicol 42(429). https://doi.org/10.1016/j.fct.2003.10.005 
20. Kwon B, Shin H, Moon HB, Ji K, Kim KT. (2016). Effects of tris (2-butoxyethyl) phosphate exposure on endocrine systems and reproduction of zebrafish (Danio rerio). Environ Pollut 214(568). http://doi.org/10.1016/j.envpol.2016.04.049

21. Liao CY, Fu JJ, Shi JB, Zhou QF, Yuan CG, Jiang GB. (2006) Methylmercury accumulation, histopathology effects, and cholinesterase activity alterations in medaka (Oryzias latipes) following sublethal exposure to methylmercury chloride. Environ Toxicol Pharmacol 22(225). https://doi.org/10.1016/j.etap.2006.03.009

22. Livak KJ, Schmittgen TD. (2001) Analysis of Relative Gene Expression Data Using Real-Time Quantitative PCR and the $2^{-\triangle \Delta C t}$ Method. Methods 25(402). https://doi.org/10.1006/meth.2001.1262

23. Lungu-Mitea, S., Oskarsson, A. and Lundqvist, J. 2018. Development of an oxidative stress in vitro assay in zebrafish (Danio rerio) cell lines. Scientific Reports 8(1): 1-

11. https://doi.org/10.1038/s41598-018-30880-1

24. Marklund S, Marklund G. Involvement of the superoxide anion radical in the autooxidation of pyrogallol and a convenient assay for superoxide dismutase. (1974). Eur J Biochem 47(469). https://doi.org/10.1111/j.1432-1033.1974.tb03714.x

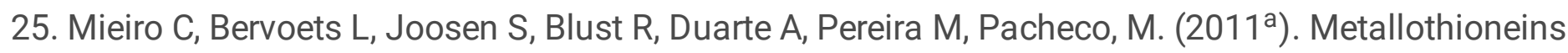
failed to reflect mercury external levels of exposure and bioaccumulation in marine fish Considerations on tissue and species specific responses. Chemosphere 85: 114. https://doi.org/10.1016/j.chemosphere.2011.05.034

26. Mieiro C, Pereira M, Duarte A, Pacheco M. $\left(2011^{\mathrm{b}}\right)$. Brain as a critical target of mercury in environmentally exposed fish (Dicentrarchus labrax) - bioaccumulation and oxidative stress profiles. Aquat Toxicol 103 (233). https://doi.org/10.1016/j.aquatox.2011.03.006

27. Mondal P, Shaw P, Bandyopadhyay A, Bhowmik AD, Chakraborty A, Sudarshan M, Chattopadhyay A. (2019). Mixture effect of arsenic and fluoride at environmentally relevant concentrations in zebrafish (Danio rerio) liver: Expression pattern of Nrf2 and related xenobiotic metabolizing enzymes. Aquat Toxicol 213(1). https://doi.org/10.1016/j.aquatox.2019.06.002

28. Osburn WO, Kensler TW. (2008). Nrf2 signaling: an adaptive response pathway for protection against environmental toxic insults. Mutation Research/Reviews in Mut Res 659(31). https://doi.org/10.1016/j.mrrev.2007.11.006

29. Patel SS, Vediya SD. (2012). A studies of toxic metals in Sarkhej lake water, Ahmedabad, Gujarat, India. Intern J of Pharm Life Sci, 3(9): 1985-1986.

30. Patel, U.N., Patel, U.D., Khadayata, A.V., Vaja, R.K., Patel, H.B. and Modi, C.M. (2021). Assessment of Neurotoxicity Following Single and Co-exposure of Cadmium and Mercury in Adult Zebrafish: Behavior Alterations, Oxidative Stress, Gene Expression, and Histological Impairment in Brain. Water Air Soil Pollut 232, 340. https://doi.org/10.1007/s11270-021-05274

31. Regoli F, Gorbi S, Frenzilli G, Nigro M, Corsi I, Focardi S, Winston G. W. (2002). Oxidative stress in ecotoxicology: from the analysis of individual antioxidants to a more integrated approach. Mar Environ Res 54(419). https://doi.org/10.1016/s0141-1136(02)00146-0 
32. Sinha AK. (1972) Colorimetric assay of catalase. Anal. Biochem 47(389). https://doi.org/10.1016/0003-2697(72)90132-7

33. Sporn MB, Liby KT. (2012). NrF2 and cancer: the good, the bad and the importance of context. Nat Rev Cancer.12(564).https://doi.org/10.1038/nrc3278

34. Srikanth K, Pereira E, Duarte AC, Ahmad I. (2013). Glutathione and its dependent enzymes' modulatory responses to toxic metals and metalloids in fish - a review. Environ Sci Pollut Res 20(2123). https://doi.org/10.1007/s11356-012-1459-y

35. Storey KB. Oxidative stress: animal adaptations in nature. (1996). Braz J Med Biol Res 29(1715).

36. Su Y, Li L, Jie H, Ning W, Wang L, Li G. (2016). Life-cycle exposure tomicrocystin-LR interferes with the reproductive endocrine system of male zebrafish. Aquat Toxicol 175 (205). https://doi.org/10.1016/j.aquatox.2016.03.018

37. Sunaina, Ansari, B. A. (2015). Biochemical markers of oxidative stress in zebrafish (Danio rerio) exposed to cadmium chloride. Annals Biol Res 6(8).6-12

38. Van Dyk, J. C., Pieterse, G. M. and Van Vuren, J. H. J. (2007). Histological changes in the liver of Oreochromis mossambicus (Cichlidae) after exposure to cadmium and zinc. Ecotoxicol Environ Safety 66(3): 432-440. https://doi.org/10.1016/j.ecoenv.2005.10.012 _

39. Zhang QF, Li YW, Liu ZH. $\left(2016^{\mathrm{a}}\right)$. Reproductive toxicity of inorganic mercury exposure in adult zebrafish: histological damage, oxidative stress, and alterations of sex hormone and gene expression in the hypothalamic-pituitary-gonadal axis. Aquat Toxicol 177(417). https://doi.org/10.1016/j.aquatox.2016.06.018

40. Zhang W, Sheng, N, Wang, M, Zhang, H, Dai, J. (2016 $)$. Zebrafish reproductive toxicity induced by chronic perfluorononanoate exposure. Aquat Toxicol 175(269). https://doi.org/10.1016/j.aquatox.2016.09.012

41. Zheng JL, Yuan SS, Wu CW, Lv ZM. (2016). Acute exposure to waterborne cadmium induced oxidative stress and immunotoxicity in the brain, ovary and liver of zebrafish. Aquat Toxicol 180(36). https://doi.org/10.1016/j.aquatox.2016.09.012

\section{Figures}



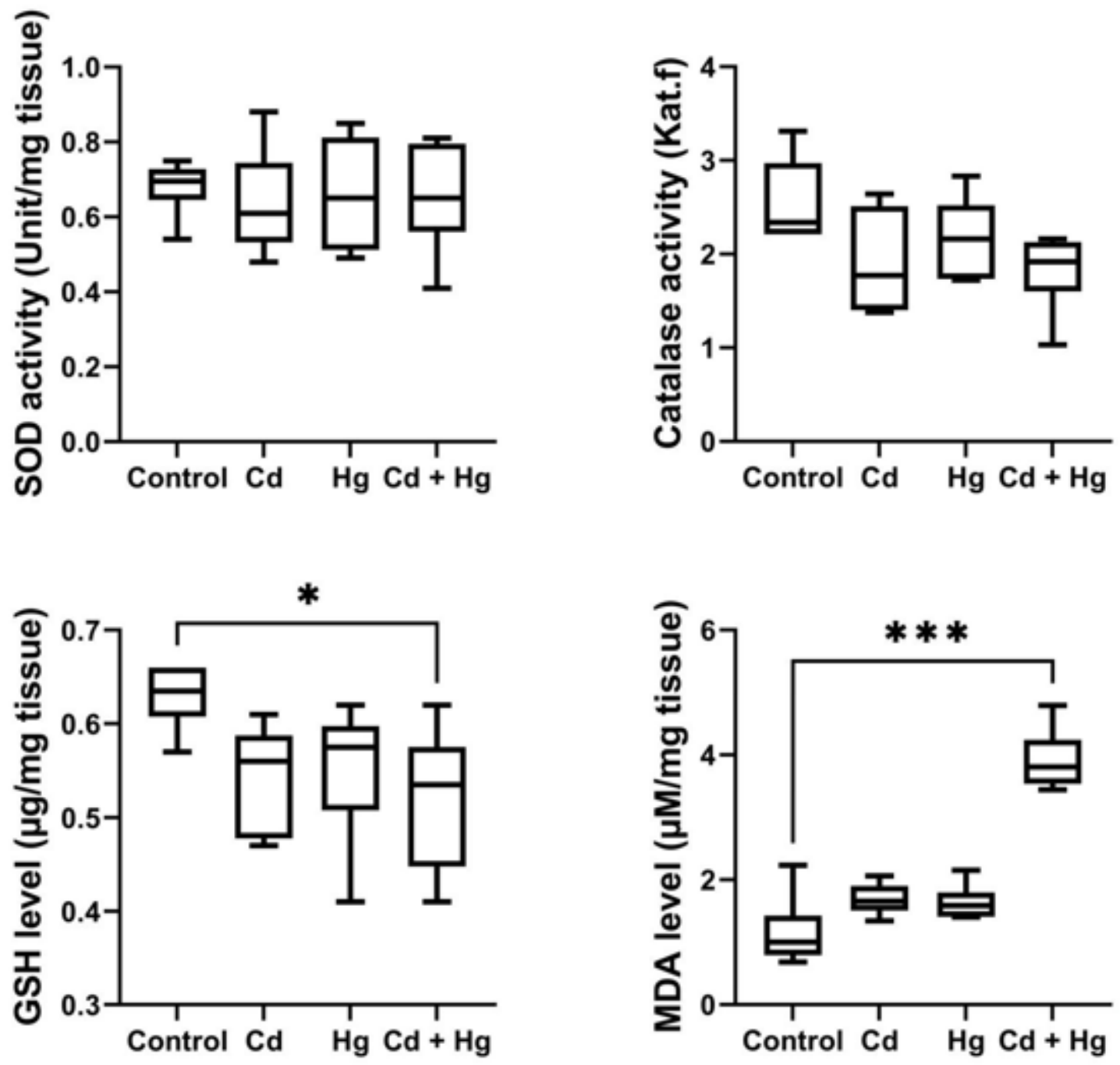

Figure 1

Oxidative stress markers in ovarian tissue of adult zebrafish exposed to $\mathrm{Cd}, \mathrm{Hg}$ and $\mathrm{Cd}+\mathrm{Hg}$ for 21 days. $\mathrm{Cd}$ : group exposed to cadmium chloride, $\mathrm{Hg}$ : group exposed to mercury chloride, $\mathrm{Cd}+\mathrm{Hg}$ : $\mathrm{Cd}$ : group exposed to cadmium chloride along with mercury chloride. * Data were analyzed by one-way ANOVA followed by Tukey's HSD test, *Indicates significant differences between the groups. *: $p<0.05, * \star: p<$ $0.01, * \star *: p<0.001$. 


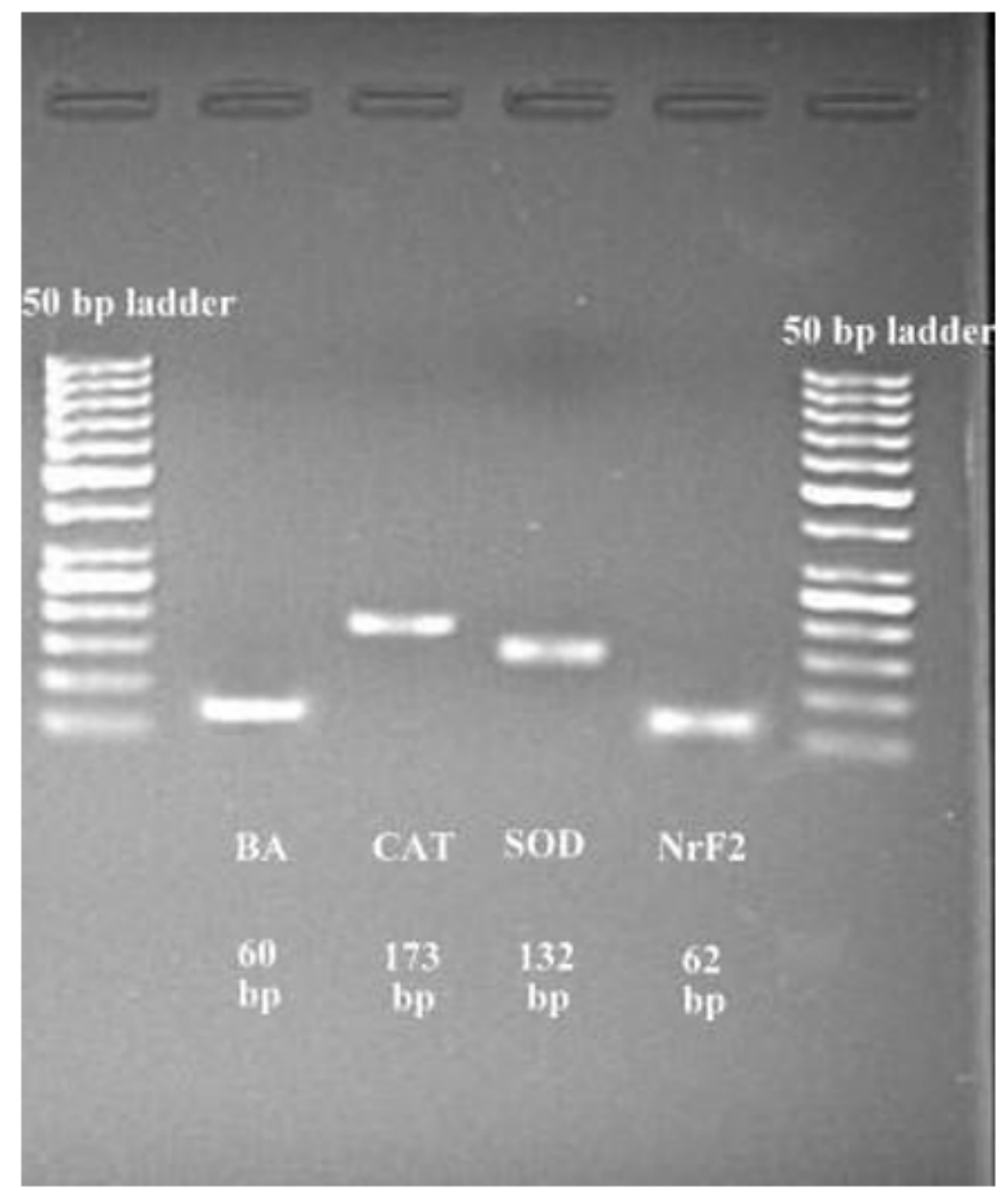

Figure 2

PCR amplification of $\beta$-actin (BA), CAT, SOD, Nrf2 from the ovarian tissue of adult zebrafish
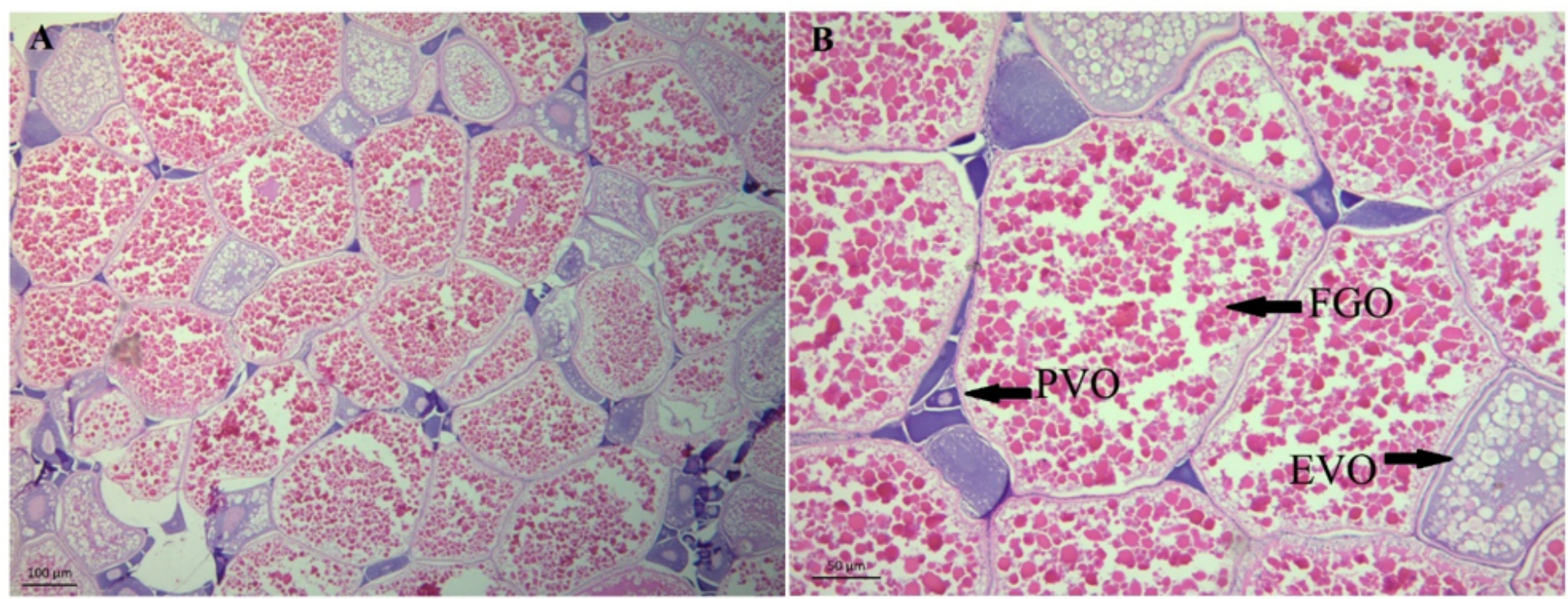

Figure 3 
Microscopic view of ovary of zebrafish of control group showing various developmental stages of oocyte like pre-vitellogenic oocyte (PVO), early-vitellogenic stage (EVO) and full-growth (Mature) oocyte (FGO) (A: Scale of $100 \mu \mathrm{m} ; \mathrm{B}, \mathrm{C}, \mathrm{D}$ : Scale of $50 \mu \mathrm{m})$.

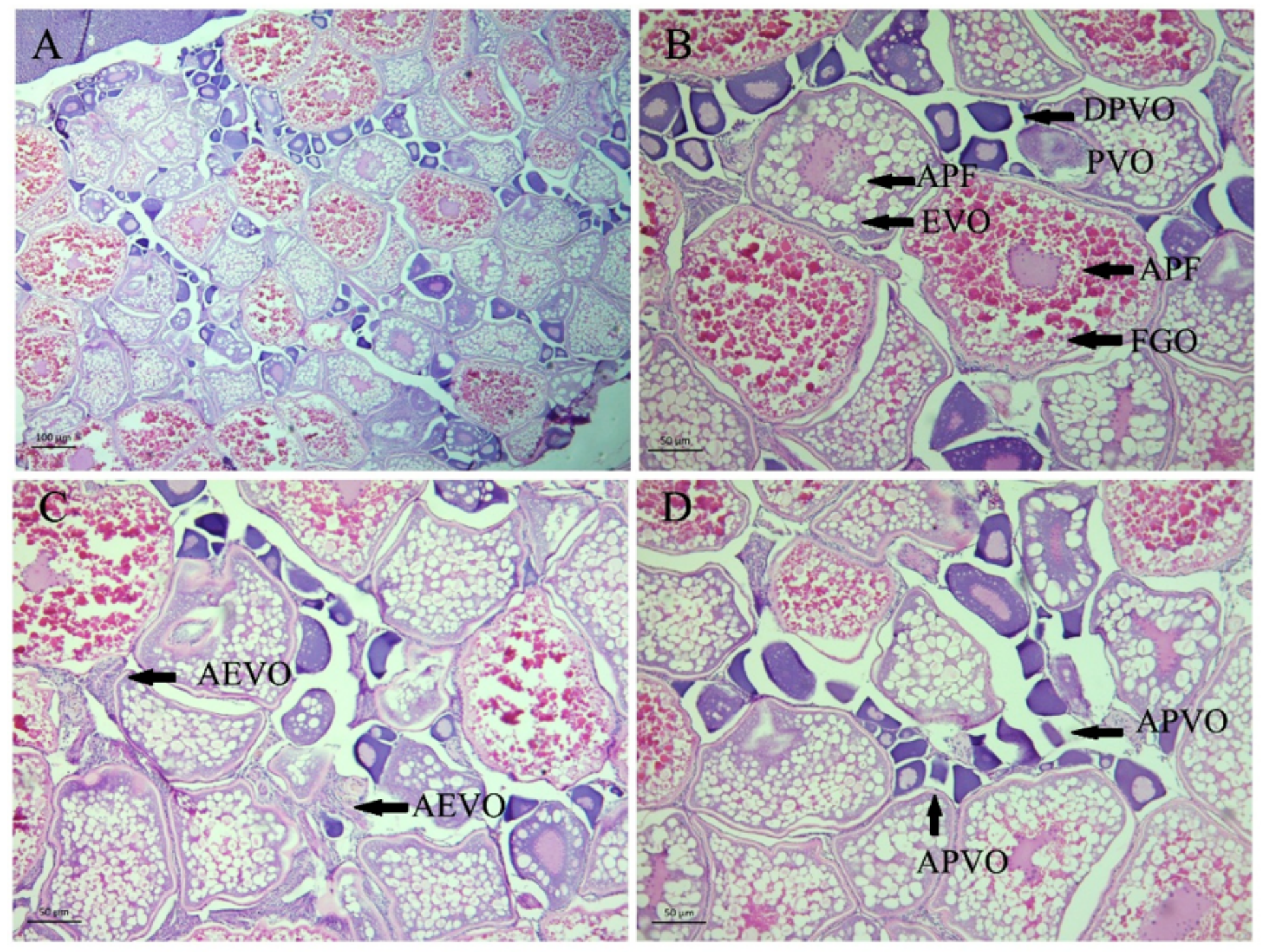

\section{Figure 4}

Microscopic view of ovary of cadmium-exposed zebrafish (A: $40 \mathrm{X}$ and B, C, D: $100 \mathrm{X}, \mathrm{H}$ \& E staining). A) Less number of full-growth (Mature) oocytes, increased number of pre-vitellogenic oocyte (PVO) and early-vitellogenic oocyte (EVO) with loss of contacts between the oocyte cell membranes and the follicular cell layer; B, C, D) accumulation of proteinaceous fluid (APF) in EVO and FGO, degenerated previtellogenic oocyte (DPVO); atretic early-vitellogenic oocyte (AEVO); atretic pre-vitellogenic oocyte (APVO) (A: Scale of $100 \mu \mathrm{m} ; \mathrm{B}, \mathrm{C}, \mathrm{D}$ : Scale of $50 \mu \mathrm{m}$ ). 

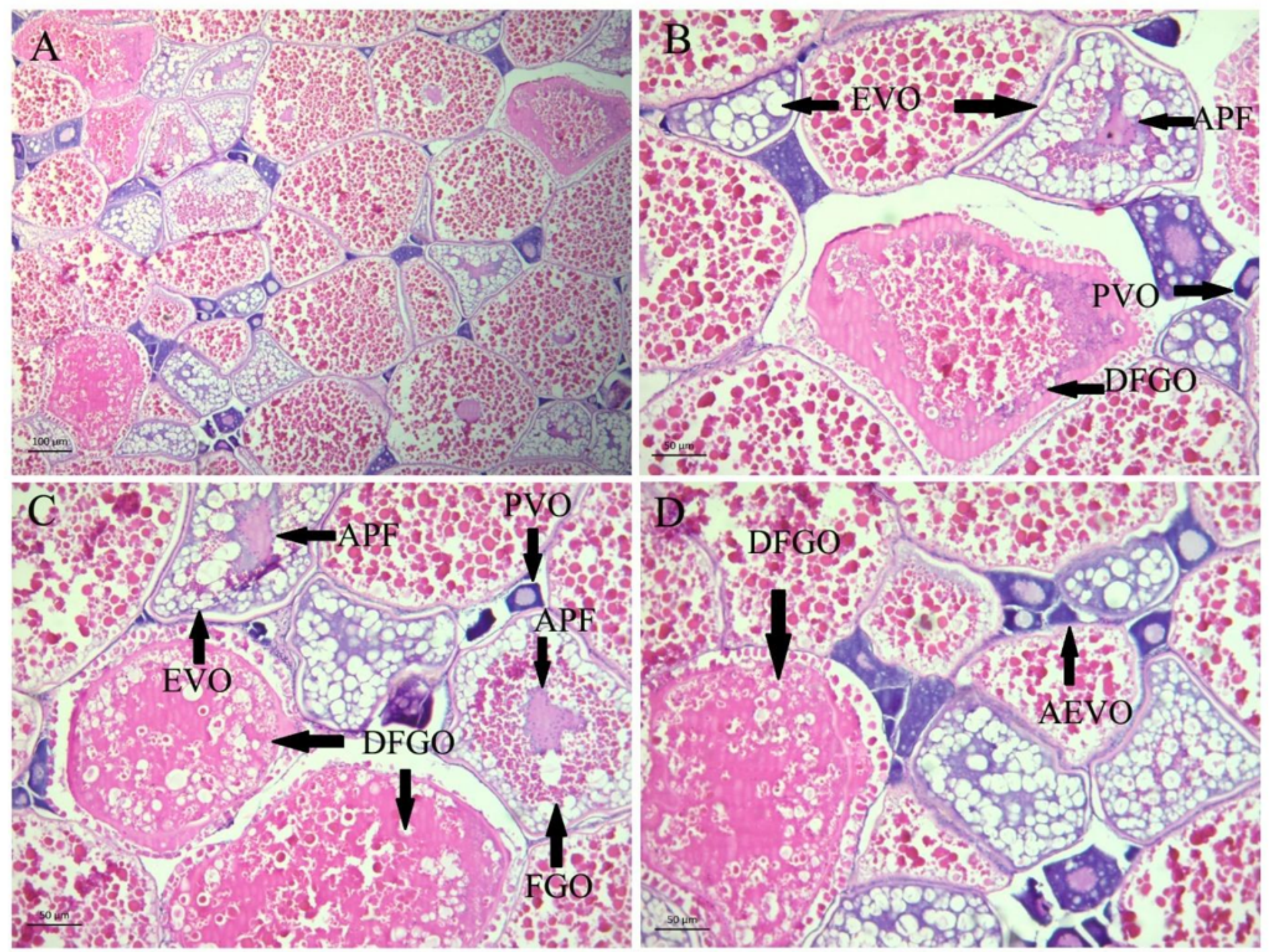

\section{Figure 5}

Microscopic view of ovary of mercury-exposed zebrafish. A) All types of oocytes (40 X); B, C, D) accumulation of proteinaceous fluid (APF) in EVO, degenerated full-growth (Mature) oocyte (DFGO) and atretic pre-vitellogenic oocyte (APVO) (A: Scale of $100 \mu \mathrm{m} ; \mathrm{B}, \mathrm{C}, \mathrm{D}$ : Scale of $50 \mu \mathrm{m})$. 

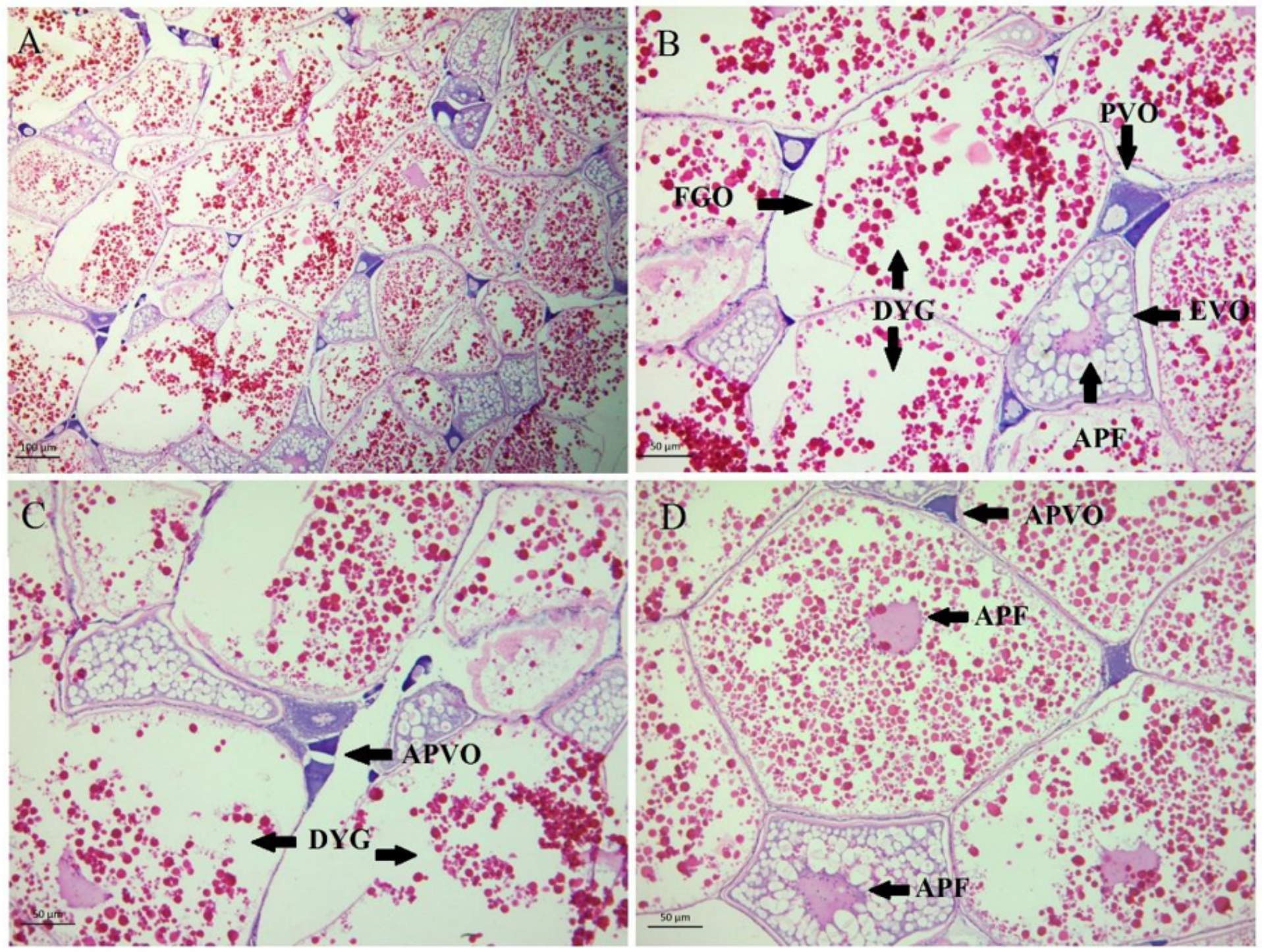

\section{Figure 6}

Microscopic view of ovary of Cadmium + mercury-exposed zebrafish. A) All types of oocytes with disorganized structure of full-growth (Mature) oocyte (40 X); B, C, D) depletion of yolk granules (DYG), accumulation of proteinaceous fluid (APF) in EVO and FGO, and atretic pre-vitellogenic oocyte (APVO) (A: Scale of $100 \mu \mathrm{m} ; \mathrm{B}, \mathrm{C}, \mathrm{D}$ : Scale of $50 \mu \mathrm{m})$. 

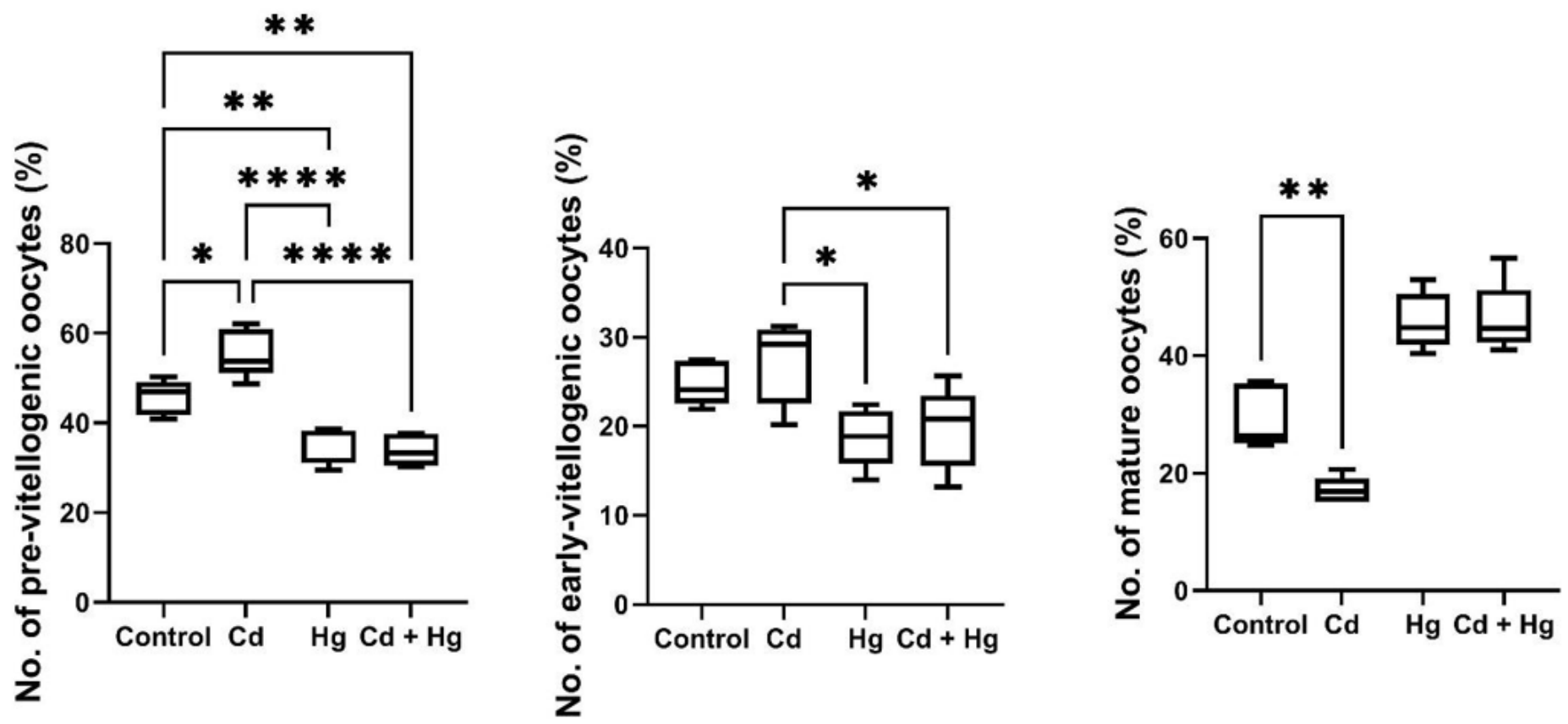

Figure 7

No. of oocytes at different stages in the ovary of adult zebrafish of different groups. Data were analyzed by one-way ANOVA followed by Tukey's HSD test, * Indicates significant differences between the groups $(*: p<0.05, * *: p<0.01, * * *: p<0.001, * * * *: p<0.0001)$
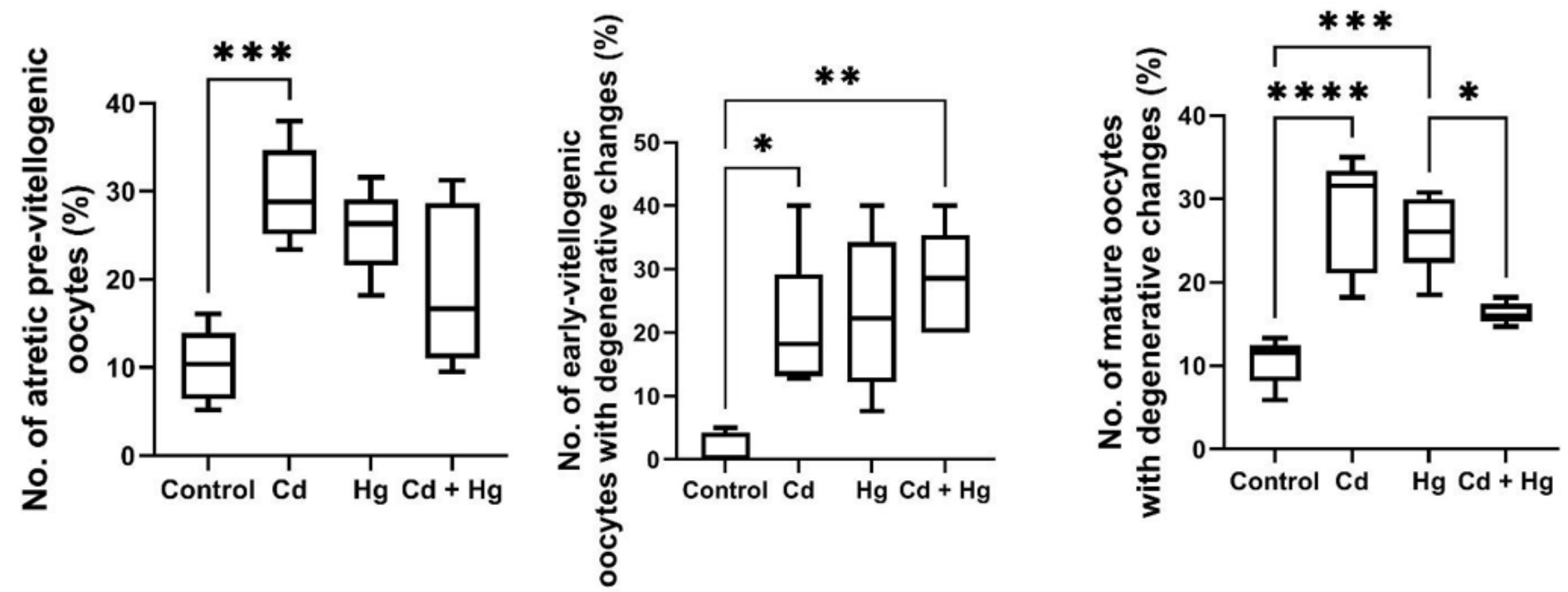

Figure 8

No. of atretic pre-vitellogenic and early-vitellogenic and mature oocytes with degenerative changes in the ovary of adult zebrafish of different groups. Data were analyzed by one-way ANOVA followed by Tukey's HSD test, * Indicates significant differences between the groups (*: $p<0.05, * \star: p<0.01, * \star *$ : $p<0.001$, $\star \star \star \star: ~ p<0.0001)$.

\section{Supplementary Files}


This is a list of supplementary files associated with this preprint. Click to download.

- SupplimentaryFile.docx

- GraphicalAbstract.png 